\title{
Studi Eksperimental Kekuatan Bending Material Gigi Tiruan Dari Resin Akrilik Berpenguat Fiber Glass Dengan Variasi Susunan Serat Penguat
}

\author{
Ika Wahyu Suryaningsih dan Yusuf Kaelani \\ Jurusan Teknik Mesin, Fakultas Teknologi Industri, Institut Teknologi Sepuluh Nopember (ITS) \\ Jl. Arief Rahman Hakim, Surabaya 60111 Indonesia \\ e-mail:y_kaelani@me.its.ac.id
}

\begin{abstract}
Abstrak-Dalam dunia kedokteran sendiri mulai banyak dilakukan penelitian-penelitian mengenai komposit, seperti pada sendi, tulang, dan gigi manusia. Misalnya saja penelitian mengenai material gigi pengganti pada manusia tujuannya untuk memperololeh material yang aman dan nyaman digunakan. Pada penelitian ini dilakukan pada material gigi tiruan dari resin akrilik berpenguat serat E-glass. Dan akan divariasikan dari pola susunan serat penguat tersebut dari tanpa hadirnya serat penguat pada material, kemudian berpenguat serat dengan pola susunan teratur dan acak pada material gigi tiruan. Pada tahap pertama diawali dengan pembuatan material uji, untuk kemudian dilakukan pengujian bending sesuai standar pengujian ASTM D790, sehingga diketahui nilai tegangan bending dari material gigi tiruan tersebut. Setelah didapatkan nilai bending maksimal dari material gigi tiruan yang divariasikan pola susunan serat penguat dengan fraksi volume $7 \%$. Maka dilakukan analisis mengenai pengaruh dari pola susunan serat yang acak dan teratur terhadap kekuatan bending dari material gigi tiruan. Dari hasil penelitian didapatkan nilai tegangan bending maksimal yang diperoleh oleh material tanpa serat penguat sebesar $42,43 \mathrm{~N} / \mathrm{mm}^{2}$. Material dengan tambahan serat penguat berpola acak sebesar $51,53 \mathrm{~N} / \mathrm{mm}^{2}$. Material dengan tambahan serat penguat berpola teratur antara $47,08 \mathrm{~N} / \mathrm{mm}^{2}-64,62$ $\mathbf{N} / \mathbf{m m}^{2}$.
\end{abstract}

Kata kunci : resin akrilik, serat penguat, pengujian bending, ASTM D790.

\section{PENDAHULUAN}

$\mathrm{K}$ OMPOSIT adalah gabungan dari dua material penyusun yang menghasilkan material baru dengan karakteristik yang lebih baik dari material awalnya. Dalam dunia kedokteran sendiri mulai banyak dilakukan penelitianpenelitian mengenai komposit seperti pada sendi, tulang, dan gigi manusia. Misalnya saja penelitian mengenai material gigi pengganti pada manusia tujuannya untuk memperololeh material yang aman dan nyaman digunakan. Penelitianpenelitian itu mulai dari bahan apa yang digunakan sebagai material gigi tiruan, komposisi komposit dari gigi tiruan, hingga jenis-jenis serat yang dapat dipakai sebagai penguat dalam material gigi tiruan.
Dalam penelitian ini dilakukan pengujian bending untuk material gigi tiruan dengan variasi serat teratur, acak, dan tanpa tambahan serat. Untuk melengkapi penelitian yang telah dilakukan sebelumnya dimana penelitian dilakukan hanya untuk mengetahui nilai keausannya dengan fraksi volume serat yang ditambahkan sebesar 7\% adalah yang memiliki nilai keausan paling kecil [1].

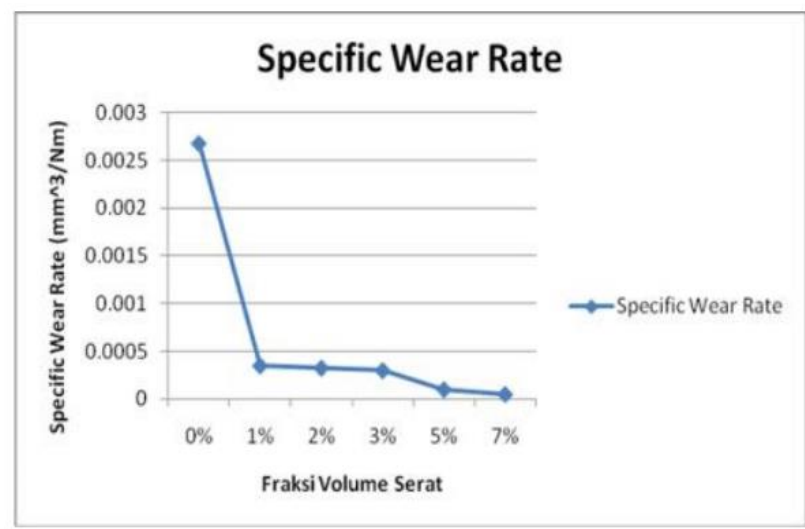

Gambar 1 grafik spesifik wear rate pada beban $2 \mathrm{~kg}$.

Selain itu juga dalam penelitian ini divariasikan dari pola susunan seratnya yaitu dengan pola serat acak dan pola serat teratur. Tujuannya adalah untuk mengetahui nilai tegangan bending maksimal yang dapat diterima oleh material gigi tiruan dengan standar pengujian ASTM D790 dengan variasi pola serat penguat yang acak dan teratur dengan fraksi volume $7 \%$.

Berdasarkan penelitian yang dilakukan oleh Zuriah Sitorus, Awan Maghfiroh, Yosephin Romania, Syahrul Humaidi pada tahun 2014 bahwa panjang serat $6 \mathrm{~mm}$ adalah yang paling baik dalam memperbaiki sifat mekanik dari resin akrilik[2].

\section{URAIAN PENELITIAN}

\section{A. Pembuatan Komposit}

Pada penelitian ini menggunakan material uji yang dibuat dari resin akrilik self cured dengan penambahan serat penguat E-glass sebesar 7\% (1,62 gram) dengan panjang 6 $\mathrm{mm}$ yang disusun secara acak dan teratur. Berdasarkan 
penelitian terdahulu bahwa semakin besar volume fraksi serat penguat yang diberikan pada resin menyebabkan laju keausan yang cenderung menurun. Namun, apabila volume serat yang ditambahkan pada material gigi tiruan lebih dari $7 \%$ dapat menimbulkan keausan fatigue. Hal ini terbukti pada fraksi serat $7 \%$ yang menunjukkan bekas pengelupasan akibat keausan fatigue[3].

Material uji pada penelitian ini dibuat berdasarkan standar ASTM D790 dengan metode pengujian three point bending. Jarak antar penumpu pada pengujian ini sebesar $80 \mathrm{~mm}$. Material uji yang digunakan memiliki ukuran panjang sebesar $\pm 96 \mathrm{~mm}$, lebar sebesar $\pm 19 \mathrm{~mm}$, dengan ketebalan sebesar $\pm 5 \mathrm{~mm}$.

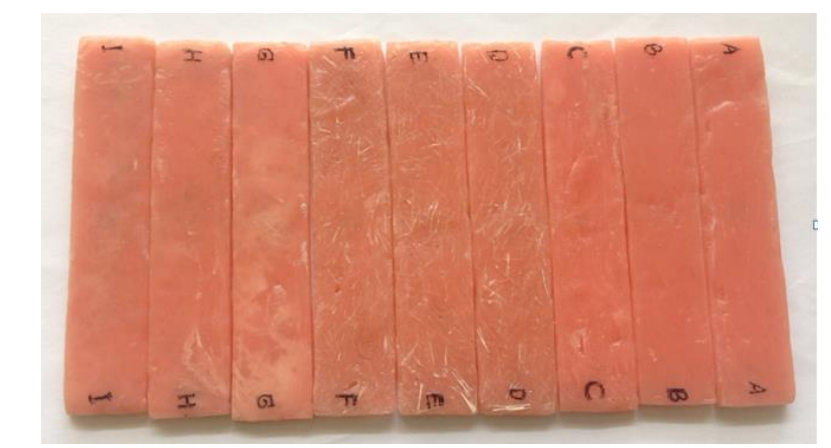

Gambar2. Material uji

Pembuatan material diawali dengan pembuatan cetakan yang terbuat dari gips agar material memiliki ukuran yang sesuai dengan standar yang sudah ditentukan. Dan material dibuat dengan mencampurkan antara monomer dan liquid,. Sebelum dituangkan kedalam cetakan harus dipastikan terlebih dahulu bahwa campuran monomer dengan liquid tadi mencapai posisi dough stage selama 1 hingga 2 menit. Kemudian material uji ditunggu hingga kering selama 30 menit. Yang membedakan antara material denga tambahan serat berpola acak dan teratur adalah cara pencampuran dan peletakan material.

\section{B. Pengujian Bending}

Gigi manusia berfungsi untuk mengunyah atau mencabikcabik makanan, sehingga makanan lebih mudah dicerna oleh tubuh. Dan mekanisme pada saat manusia mengunyah atau menggigit makanan dapat diumpamakan seperti dikenai beban pada gigi tersebut sehingga menimbulkan bending. Makanan yang digigit atau dikunyah akan memberikan tekanan pada gigi. Oleh sebab itu dilakukan pengujian bending karena pengujian ini dilakukan untuk mengukur kekuatan material karena pembebanan yang diberikan, sehingga dapat diketahui kekuatan dari material gigi tiruan. Pengujian bending ini menggunakan metode three point bending, caranya adalah spesimen uji ditumpu pada kedua ujungnya dan diberikan beban diantara kedua penumpu tersebut hingga spesimen uji tersebut rusak atau patah. [4].

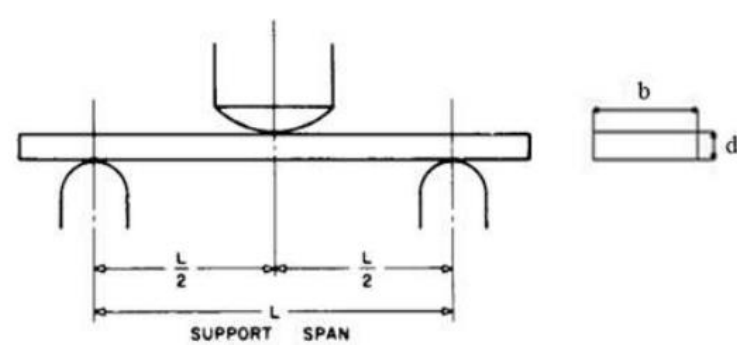

Gambar 3. Pengujian bending metode three point bending [5]

Dari pengujian bending yang dilakukan akan didapatkan nilai beban yang mampu diterima material gigi tiruan hingga patah. Pengujian dilakukan dengan menggunakan alat uji bending autograph tipe AG 10 TE Shimadzu. Pada gambar 4 juga dapat diketahui skema dari pengujian bending yang dilakukan pada material uji gigi tiruan.

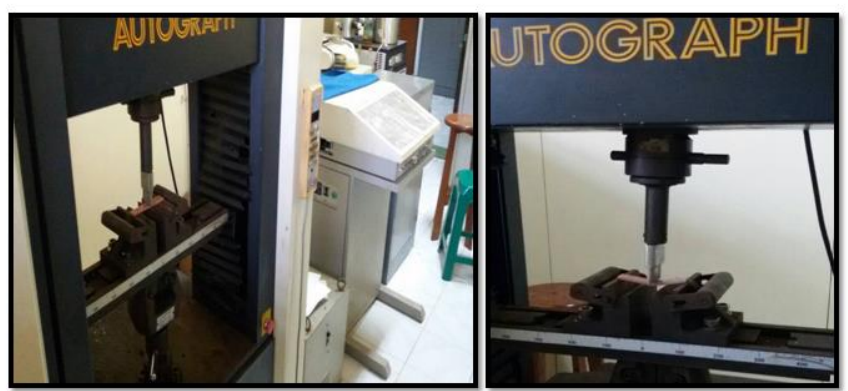

Gambar 4. Mesin uji bending autograph AG 10 TE, Shimadzu

\section{HASIL DAN PEMBAHASAN}

Berdasarkan standar ASTM D790 untuk mengetahui nilai tegangan bending maksimal pada material gigi tiruan seperti berikut :

$$
\sigma=\frac{a p x L}{2 b x d^{2}}
$$

Tegangan bending maksimal atau $\sigma$ dihitung berdasarkan persamaan (1) dalam satuan Mpa, $\mathrm{P}$ adalah beban maksimal yang mampu diterima oleh material uji dalam satuan kgf. L adalah jarak antar penumpu, b adalah lebar dari material uji dan d merupakan ketebalan material uji (dalam satuan mm). Kemudian akan didapatkan nillai beban yang mampu diterima material uji dan dari pengujian yang telah dilakukan. Setelah itu dilakukan perhitungan nilai tegangan bending maksimal pada material uji gigi tiruan berdasarkan persamaan (1). Berikut ini adalah tabel yang menunjukkan nilai tegangan bending pada tiap material : 
Tabel 1 nilai tegang bnding maksimal material gigi tiruan.

\begin{tabular}{|c|c|c|c|c|c|}
\hline No & \multicolumn{2}{|c|}{ Material Uji } & Load & & \\
\hline 1 & \multirow{3}{*}{$\begin{array}{c}\text { Tidak ada } \\
\text { serat penguat }\end{array}$} & I & 186,2 & 42,46 & \multirow{3}{*}{42,43} \\
\hline 2 & & II & 196 & 43,15 & \\
\hline 3 & & III & 178,36 & 41,68 & \\
\hline 4 & \multirow{3}{*}{$\begin{array}{l}\text { Pola susunan } \\
\text { serat ukuran } \\
6 \mathrm{~mm} \text { acak }\end{array}$} & I & 212,66 & 50,09 & \multirow{3}{*}{51,35} \\
\hline 5 & & II & 212.66 & 50,52 & \\
\hline 6 & & III & 227,36 & 53,44 & \\
\hline 7 & \multirow{3}{*}{$\begin{array}{l}\text { Pola susunan } \\
\text { serat ukuran } \\
6 \mathrm{~mm} \text { teratur }\end{array}$} & $\mathrm{I}$ & 295,96 & 64,63 & \multirow{3}{*}{55,78} \\
\hline 8 & & II & 215,6 & 47,08 & \\
\hline 9 & & III & 254,8 & 55,64 & \\
\hline
\end{tabular}

Selain itu, nilai tegangan bending juga dapat dilihat pada gambar 5. Perbedaan nilai yang dimiliki antara material dengan tambahan serat berpola acak dan material dengan tambahan serat berpola teratur adalah jumlah serat pada penampang yang patah untuk material dengan tambahan serat berpola teratur lebih banyak. Pada material dengan tambahan serat berpola acak, posisi seratnya yang tumpang tindih tidak beraturan menyebabkan jumlah serat yang mampu menyerap beban tidak banyak. Dan pada material dengan tambahan serat berpola teratur, jumlah seratnya cukup untuk menerima beban yang besar karena posisinya yang teratur sehingga serat yang terdistribusi ke seluruh material mampu menerima beban secara maksimal. Namun nilai yang diperoleh kurang seragam jika dibandingkan dengan material dengan tambahan serat berpola acak.

tegangan bending vs variasi serat

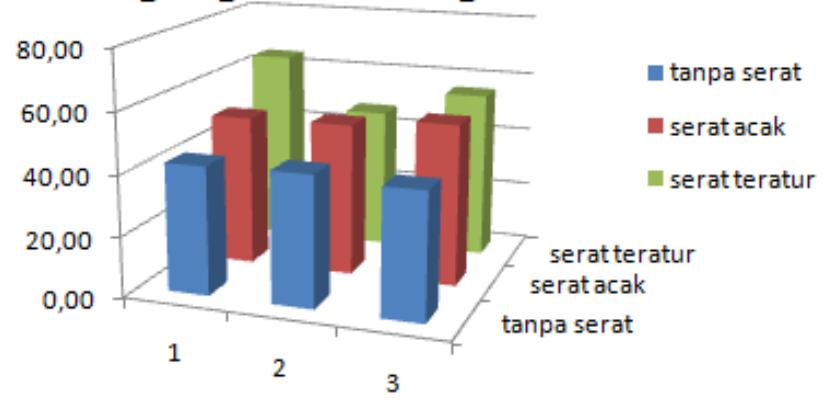

Gambar 5. Grafik tegangan bending tiap material uji.

Untuk melengkapi analisis dan pembahasan pada material gigi tiruan, maka analisis juga dilakukan dengan menggunakan foto material uji untuk mengatahui pola patahan yang terjadi pada material uji pada masing-masing variasi pola susunan serat penguat.
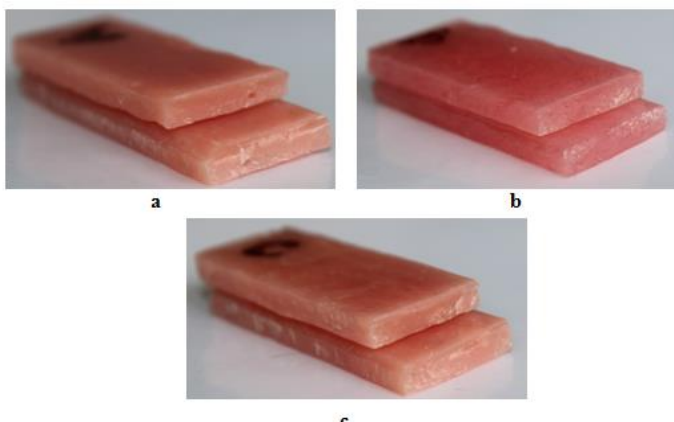

Gambar 6. Material tanpa tambahan serat penguat.
Pada gambar 6 menunjukkan gambar material uji tanpa adanya tambahan serat penguat. Melalui pola patahan yang terlihat juga dapat diketahui bahwa bagian permukaan yang patah tidak memiliki serabut dan cenderung halus. Hal tersebut menunjukkan bahwa material tersebut adalah getas. Mekanisme patah yang terjadi pada material ada dua, yaitu material yang langsung mengalami patah ketika diberi beban dan material yang patah dengan diawali adanya delaminasi atau regangan terlebih dahulu. Untuk material tanpa adanya tambahan serat tersebut langsung patah tanpa mengalami proses penyerapan beban oleh serat karena tidak ada hadirnya serat penguat pada material tersebut.

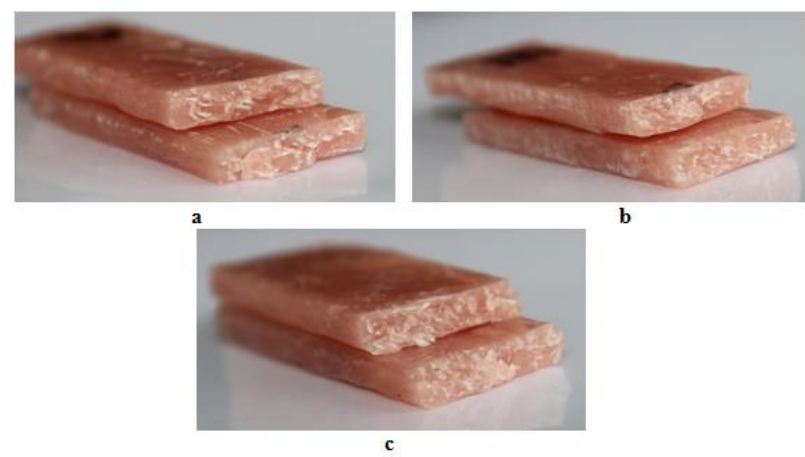

Gambar 7. Material dengan tambahan serat berpola acak.

Pada gambar 7 tersebut menunjukan gambar material uji dengan adanya tambahan serat berpola acak. Melalui pola patahan pada material juga dapat diketahui bahwa pada bagian permukaan material yang patah tersebut permukaanya kasar. Dan itu menunujukan bahwa material gigi tiruan dengan hadirnya serat penguat memiliki sifat yang ulet. Kemudian dilakukan analisis pada semua material uji dengan tambahan serat berpola acak dimana serat patah bersamaan dengan patahnya material karena serat dengan resin yang terdapat pada material tersebut dapat menyatu dengan baik. Sehingga material tidak mengalami delaminasi terlebih dahulu. Namun, karena posisi serat yang acak atau saling tumpang tindih menyebabkan serat rawan patah yang mengakibatkan beban yang diserap juga kurang maksimal.

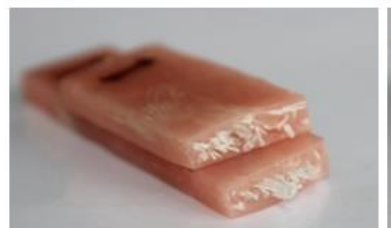

a

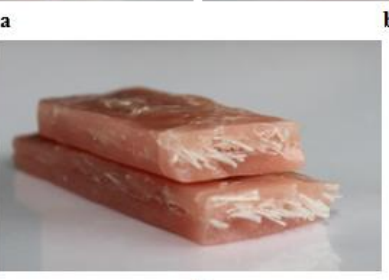

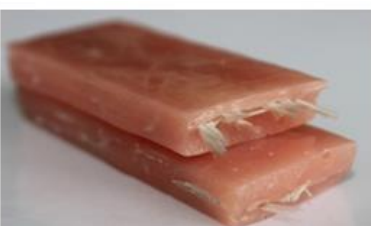

Gambar 8. Material dengan tambahan serat berpola terataur. 
Pada gambar 8 di atas menunjukan gambar material uji dengan adanya tambahan serat berpola teratur. Melalui permukaan patahan pada material dapat diketahui bahwa dengan hadirnya serat penguat, material akan memiliki sifat yang ulet. Pada material yang pertama memiliki nilai tegangan bending yang paling tinggi karena dalam proses pembuatannya antara resin akrilik dengan serat penguatnya dapat menyatu dengan baik. Hal ini dapat diketahui dari permukaan patahnya bahwa serat pada material pertama turut patah bersama dengan resin tanpa meninggalkan lubang pada sisi material yang lainnya. Pada material kedua bagian permukaan patahnya terlihat bahwa seratnya tidak turut patah bersamaan dengan patahnya material. Ini dapat terjadi karena antara serat dengan resin kurang dapat menyatu dengan baik, sehingga serat mengalami delaminasi. Jadi ketika diberi beban material tersebut mampu menyerap beban secara maksimal dan memiliki nilai tegangan bending yang paling tinggi.

Gambar 9 di bawah ini menunjukkan bahwa material uji yang terdiri atas resin dan serat yang diberikan pembebanan daei bagian atas. Dengan posisi beban terhadap material dapat terlihat seperti gambar 9 dan orientasi serat yang disusun secara teratur.

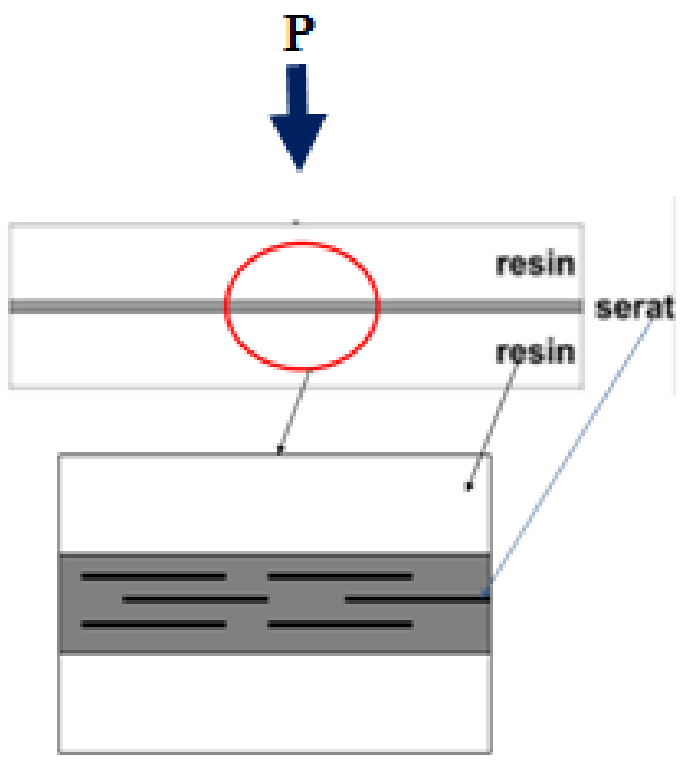

Gambar 9. Posisi serat pada material uji.

Pada gambar 10, terlihat bahwa material berpola serat teratur yang kedua, mengalami patah yang diawali dengan adanya delaminasi. Delaminasi adalah terlepasnya ikatan antar lamina khusus pada komposit dengan penguat. Karena adanya delaminasi pada material kedua tersebut serat yang semakin lama diberi beban akan membuat serat tersebut terlepas dengan resinnya, dan pada gambar 10 ditunjukan dengan bagian yang berwarna kuning. Karena beban yang diberikan, material patah secara cepat dari bagian atas lapisan serat dan berlanjut pada bagian bawah serat. Sehingga menimbulkan permukaan patah yang yang tidak rata pada material.

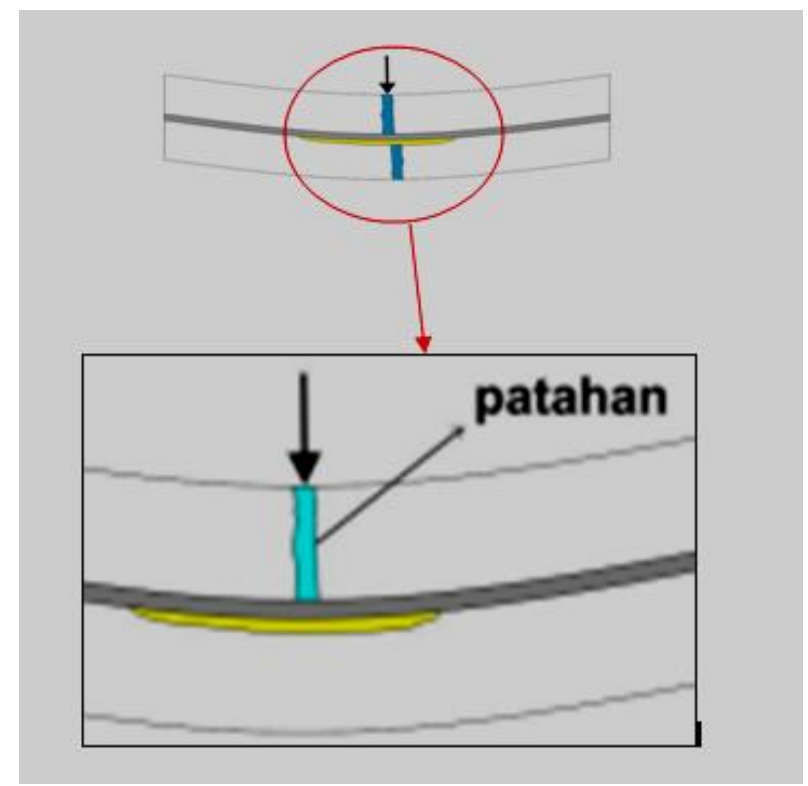

Gambar 10. Mekanisme patahan pada material.

Gambar 11 di bawah ini adalah gambar material setelah patah. Karena diawali oleh delaminasi pada serat ketika beban mulai diberikan lalu material patah secara cepat di lapisan yang bebeda. Terlihat bahwa patahan material uji tersebut pada permukaan patah diatas lapisan serat berbeda dengan pada bagian bawahnya. Selain itu terdapat lubang bekas menempelnya serat pada salah satu bagian material. Sehingga beban yang mampu diterima oleh material tambahan serat berpola teratur yang kedua tidak dapat maksimal seperti halnya material yang pertama.

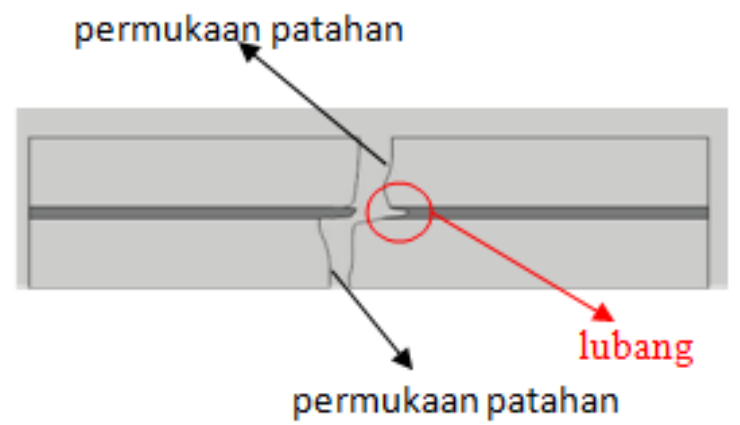

Gambar 11. Patahan material hasil pengujian.

\section{KESIMPULAN}

Tegangan bending maksimal yang mampu diterima material gigi tiruan untuk material tanpa tambahan serat penguat sebesar 42,43 N/mm². Material dengan tambahan serat penguat berpola acak sebesar $51,35 \mathrm{~N} / \mathrm{mm}^{2}$. Dan material dengan tambahan serat penguat berpola teratur

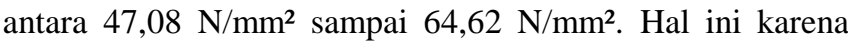
komposit material gigi tiruan dengan susunan serat penguat berpola teratur lebih mudah mengalami delaminasi. Oleh sebab itu, kekuatan bending material komposit dengan tambahan serat teratur memiliki harga yang bervariasi. 


\section{UCAPAN TERIMA KASIH}

Penulis Ika W.S ingin mengucapkan terima kasih kepada Laboratorium Fakultas Kedokteran Gigi Universitas Airlangga yang telah membantu dalam pembuatan material uji. Dan kepada Laboratorium Dasar Bersama Universitas Airlangga yang telah membantu dalam pelaksanaan pengujian bending untuk pengambilan data.

\section{DAFTAR PUSTAKA}

[1] Widianingrum, Dwi Tarina, Studi Eksperimental Laju Keausan (Spesific Wear Rate) Resin Akrilik dengan Penambahan Serat Penguat pada Dental Prosthesis, Jurnal Teknik ITS Vol.1, ISSN: 2301-9271,(2012).

[2] Zuriah Sitorus, Awan Maghfirah, Yosephin Romania, Syahrul Humaidi. 2014. Sifat Mekanik Gigi Tiruan Akrilik dengan Penguat Serat Gelas. Departemen Fisika, FMIPA, Universitas Sumatera Utara, Medan.

[3] Kaelani,Yusuf, Laju Keausan (Spesific Wear Rate) Material Resin Akrilik Dengan Penambahan Serat Penguat Pada Dental Prosthesis, Proceding SNTTM Teknik Mesin XI dan Thermofluid IV,(2012).

[4] Annur, Hikmah, Pengujian Bending Biomaterial Hidroksiapatit Dari Tulang Sapi sebagai Prosthesys Sendi Rahang(TMJ) pada manusia, Jurnal Teknik ITS Vol 4., ISSN : 2337-3539, (2015).

[5] Annual Book of ASTM Standards, D790. Standard Test Method for Flexural and Reinforced Plastics AND Electrical Insulating Material (Metric). American Society for Testing and Material (1984). 